\title{
Sistem Pendukung Keputusan Dalam Pemilihan Biji Kelapa Sawit Menggunakan Metode MOORA
}

\author{
Inne Irianti Sinon ${ }^{1}$, Anief Fauzan Rozi ${ }^{2}$ \\ Program Studi Sistem Informasi, Fakultas Teknologi Informasi, Universitas Mercu Buana Yogyakarta, \\ J1. Wates Km. 10 Yogyakarta 55753, Indonesia \\ Email: anief@mercubuana-yogya.ac.id
}

\begin{abstract}
ABSTRAK
Kelapa sawit merupakan jenis tumbuhan yang termasuk dalam keluarga tumbuhan genus elais dan arecaceae. Tumbuhan kelapa sawit banyak di tanam di Indonesia yang seb tropis. Buah kelapa sawit sendiri di fungsikan untuk diambil buahnya yang mana berfungsi sebagai bahan baku utama pembuatan minyak kelapa sawit. untuk mendapatkan hasil panen yang maksimal maka para pelaku usaha wajib memilih biji kelapa sawit terbaik, agar nantinya hasil panen yang ditentukan jugaakan lebih maksimal. Berdasarakan pembahasan diatas maka didapat kan suatu masalah yaitu dalam pemilihan biji kelapa sawit yang terbaik. Berdasarkan masalah tersebut maka dibutuhkan suatu sistem informasipendukung keputusan yang mana akan menghasilkan suatu output rekomendasi keputusan dalam pemilihan biji kelapa sawit terbaik. Dengan demikian dapat diusulkan pembuatan susatu sistem pendukung keputusan pemilihan biji kelapa sawit yang mana dalam proses perhitungannya menggunakan metode MOORA. Dari hasil uji yang dilakukan dari 5 alternatif didapatkan hasil Biji Kelapa Sawit Grad Amemiliki nilai tertinggi yaitu dengan nilai 31,87 .
\end{abstract}

Kata kunci : SPK, Sistem Penunjang Keputusan, Biji Kelapa Sawit, MOORA

menjadi bahan baku minyak goreng. Sisa

\section{PENDAHULUAN}

PT. Hendrison Inti Persada (HIP) Adalah perusahan kelapa Sawit yang beroprasi di Kabupaten Sorong Provinsi Papua Barat, Kelapa Sawit tumbuhan industri/ perkebunan yang berguna sebagai penghasil minyak masak, minyak industri, maupun bahan bakar (lina Arliana Nur Kadim, 2014) perkebunan kelapa sawit dapat menghasilkan keuntungan besar sehingga banyak hutan dan perkebunan lama dikonversikan menjadi perkebunan kelapa sawit. Penyebaran kelapa sawit di indonesia berada pada pulau Sumatra, Kalimantan, Jawa, Sulawesi, papua dan papua Barat Di papua barat. Buah kelapa sawit di gunakan sebagai bahan mentah minyak goreng, margarine, sabun, kosmetika, industri farmasi. Bagian terinti yang di kelolah kelapa sawit adalah buah. Bagian daging dari buah kelapa sawit manghasilkan minyakmentah yang di olah pengolahanya digunakan sebagai bahan campuran makanan ternak dan difermentasikan menjadi kompos. Sektor pertanian merupakan sektor yang sangat penting peranannya di dalam perekonomian di berbagai negara berkembang termasuk Indonesia.

Untuk pendukung keputusan pemilihan biji kelapa sawit, metode yang digunakan adalah salah satu metode SPK (Sistem Pendukung Keputusan) yaitu metode MOORA (Multi Objective Optimization by Ratio Analysis). Dari pemilihan biji kelapa sawit tersebut terdapat beberapa kriteria yang wajib dipertimbangkan dalam pemilihan biji kelapa sawit yakni Kualitas Biji Kelapa Sawit, Nilai kriteria biji kelapa sawit, memberikan bobot, menghitung nilai Normalisasi.

PT.Hendrison Inti Persada saat ini masihmenggunakan metode manual untuk menentukan Kualitas Biji Kelapa Sawit dengan kriteria tersebut, sehingga timbul 
permasalahan dalam pemilihan biji Kelapa Sawit pada perusahan HIP.

Oleh karena itu pada penelitian ini ingin membantu pihak PT. Hendrison Inti Persada

(HIP) dalam Pembuatan Aplikasi sistem penunjang keputusan untuk pemilihan biji kelapa sawit untuk mempermudah dan membantu rekomendasi internal PT. Hendrison Inti Persada sesuai dengan kriteria kerja. Dengan mengangkaat topik " Sistem Pendukung Keputusan Dalam pemilihan Biji Kelapa Sawit menggunkan metode MOORA (Multi Objective Optimization by Ratio Analysis)" dengan studi kasus di PT. Hendrison Inti Persada Kabupaten sorong.

\section{TINJAUAN PUSTAKA}

Dalam penelitia berjudul "Sistem Pendukun Keputusan Pemilihan Bibit Kelapa Sawit Menggunakan Metode Preference Ranking Organization Method

\section{Enrichment \\ Evaluation}

(PROMETHEE)" membahas tentang tanaman kelapa sawit merupakan salah satu komuditas perkebunan yang memiliki peranpenting pada sektor ekonomi untuk meningkatkan devisa negara dan memenuhi kesejahtraan kebanyakan masyarakat Indonesia, untuk mendapatkan hasil yang baik maka pentingnya menentukan bibit tanaman kelapa sawit yang unggul. Olehkarena itu, diperlukan suatu sistem pendukung keputusan dalam menentukan bibit kelapa sawit, dimana sistem ini akan menghasilkan perengkingan bibit kelapa sawit terbaik dari jenis bibit kelapa sawit yang unggul (Girsang S. F., 2016).

Dalam penelitian berjudul "Sistem Pendukung Keputusan Pemilihan Jenis Bibit Unggul Kelapa Sawit Dengan Metode Analytic Hierarchy Process (AHP)" membahas tentang kebutuhan akan ketersediaan bibit kelapa sawit berkualitas dengan kuantitas yang terus meningkat sejalan dengan meningkatnya kebutuhan penduduk dunia akan minyak sawit. Setiap tahun produksi kelapan sawit selalu meningkat (BKPM, 2016). Dan dapat disimpulkan bahwa produksi dan juga lahanperkebunan kelapa sawit terus mengalami peningkatan sejak tahun 2008 sampai dengan tahun 2016. Oleh karena itu penulis tertarik untuk membangun sebuah sistem pendukung keputusan menentukan bibit

kelapa sawit terbaik dengan menggunakan metode Analytic Hierarchy Process (AHP) yang nantinya harapan penulis dengan adanya sistem tersebut dapat membantu para pelaku usaha kelapa sawit untuk menentukan bibit kelapa sawit yang unggul (Fazliani1, 2017).

Dalam hal ini pentingnya pemilihan bibit kelapa sawit yang unggul yang mana akan menghasil kan hasil panen yang maksimal. Menurut penulis pemanfaatan sistem pendukung keputusan dengan menggunakan metode Promethee II sangat tepat jika diterapkan pada permasalahan pemilihan bibit kelapa sawit yang unggul, penelitian diawalai dengan mencari nilai bobot pada setiap atribut, setelah itu akan dilakukan proses perankingan yang akan menentukan kriteria dan alternatif yang optima. Diman harapan penulis sistem tersebut dapat membantu para petani untuk menentukan bibit kelapa sawit yang unggul (Andysah P U Siahaan, 2018).

\subsection{LANDASAN TEORI}

\subsubsection{Kelapa Sawit}

Kelapa sawit (Elaeis Guineesis Jacq) adalah salah satu komudite perkebunan yang penting di Indonesia, dikarenakan sumber perolehan devisa negara yang cukup besar. Data tersebut juga tercantum pada luar area perkebunan kelapa sawit 
yang ada pada Bengkulu mencapai 308.669

ha, dengan produksi sebesar 914.103 ton sawit.

Dalam pengembangan usaha kelapa sawit, menentukan bibit kelapa sawit yang unggul adalah salah satu faktor penting yang menentukan hasil panen yang maksimal. Pembibitan merupakan langkah awal dari seluruh rangkaian kegiatan budidaya tanaman kelapa sawit. Bibit kelapa sawit yang baik memiliki kekuatan dan penampilan tumbuh yang optimal serta berkemampuan dalam menghadapi kondisi lingkungan yang buruk (Filsafat Waruwu, 2018).

\subsubsection{Sistem Pendukung Keputusan}

Konsep Sistem Pendukung Keputusan (SPK) atau Decision Support System (DSS) pertama kali diperkenalkan oleh Michael S. Scott Morton pada awal tahun 1970-an, yangselanjutnya dikenal dengan istilah Management Decision Systems. Konsep SPK ditandai dengan sistem interaktif berbasis komputer yang membantu pengambilan

\section{keputusan}

dengan memanfaatkan

data dan model untuk menyelesaikan masalah yang bersifat tidak terstruktur dan semi terstruktur (Riadi, 2016).

\subsubsection{Multi Objective Optimization On The Basic Of Ratio Analysis (MOORA)}

Metode MOORA pertama kali dikenalkan oleh Braures dan Zavadskas pada tahun 2006, pada saat dikenalkan metode MOORA digunakan untuk memecahkan banyak permasalahan ekonomi amanjeial dan konstruksi dengan menggunakan perhitungan rumus matematikan dengan hasil yang akurat. Pada awalnya Braures mengenalkan metode MOORA untuk memecahakan berbagai

masalah pengambilan keputusan yang rumit pada lingkungan pabrik (dsn, 2018).

\section{METODOLOGI PENELITIAN}

Metodelogi yang dilkakuan adalah melakukan proses penelitian dari perancangan sistem sampai dengan sistem tersebut selesai untuk gambaran alur penelitian dapat dilihat pada Gambar 1.

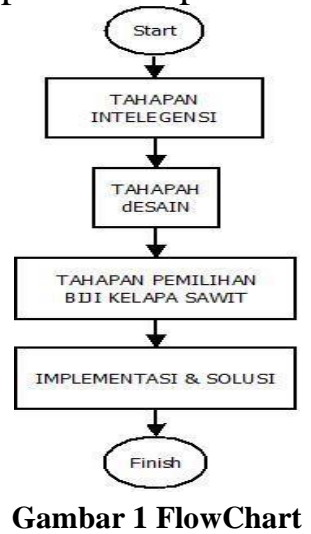

\section{Hasil Pembahasan}

Berikut merupakan hasil penjabaran dari hasil pembahasan tentang analisa keputusan dalam menentukan biji kelapa sawit terbaik yang mana menggunakan metode perhitungan MOORA.

\subsection{Penentuan Kriteria}

Kriteria adalah parameter-parameter yang digunakan untuk menghitung datdata alternatif yang mana parameter-parametr inimerupakan parameter yang berpengaruh dalam pengambilan keputusan pemilihan biji kelapa sawit. Kriteria sistem pendukung keputusan pemilihan biji kelapa sawit menggunakan metode MOORA dapat dilihat pada tabel berikut.

Tabel 1

Kriteria

\begin{tabular}{|c|c|c|c|}
\hline Kriteria & Tipe & Bobot & Data Value \\
\hline Fraksi Kematangan & Benefit & 35 & Fraksi \\
\hline Harga & Cost & 25 & Harga \\
\hline Jarak Pengambilan & Cost & 15 & Jarak \\
\hline $\begin{array}{c}\text { Pernyatan } \\
\text { Karantina }\end{array}$ & Benefit & 25 & Karantina \\
\hline
\end{tabular}

4.2 Penentuan Alternatif 
Alternatif disini adalah data-data yang akan dihitung pada sistem penunjang keputusan pemilihan biji kelapa sawit menggunakan metode MOORA yang mana nantinya akan menghasil output perankingan alternatif terbaik sampai dengan alternatifyang buruk. Data alternatif akan digambarkan pada Tabel 2 .

\begin{tabular}{|l|c|c|c|c|}
\hline \multirow{2}{*}{ Alternatif } & \multicolumn{4}{|c|}{ Kriteria } \\
\cline { 2 - 5 } & $\begin{array}{c}\text { Fraksi } \\
\text { Kemata } \\
\text { ngan }\end{array}$ & Harga & $\begin{array}{c}\text { Jarak } \\
\text { Pengam } \\
\text { bilan }\end{array}$ & $\begin{array}{c}\text { Pernyata } \\
\text { an } \\
\text { Karantin } \\
\text { a }\end{array}$ \\
\hline $\begin{array}{l}\text { Data } \\
\text { Sampel Biji } \\
\text { Kelapa } \\
\text { Sawit Grad } \\
\text { A }\end{array}$ & 7 & 5 & 1 & 5 \\
\hline $\begin{array}{l}\text { Data } \\
\text { Sampel Biji } \\
\text { Kelapa } \\
\text { Sawit Grad } \\
\text { B }\end{array}$ & 6 & 5 & 2 & 3 \\
\hline $\begin{array}{l}\text { Data } \\
\text { Sampel Biji } \\
\text { Kelapa } \\
\text { Sawit Grad } \\
\text { C }\end{array}$ & 5 & 5 & 4 & 3 \\
\hline $\begin{array}{l}\text { Data } \\
\text { Sampel Biji } \\
\text { Kelapa }\end{array}$ & 2 & 1 & 5 & 3 \\
\hline
\end{tabular}

\begin{tabular}{|l|c|c|c|c|}
\hline \multirow{2}{*}{ Alternatif } & \multicolumn{4}{|c|}{ Kriteria } \\
\cline { 2 - 5 } & $\begin{array}{c}\text { Fraksi } \\
\text { Kemata } \\
\text { ngan }\end{array}$ & Harga & $\begin{array}{c}\text { Jarak } \\
\text { Pengam } \\
\text { bilan }\end{array}$ & $\begin{array}{c}\text { Pernyata } \\
\text { an } \\
\text { Karantin } \\
\text { a }\end{array}$ \\
\hline $\begin{array}{l}\text { Sawit Grad } \\
\text { D }\end{array}$ & & & & \\
\hline $\begin{array}{l}\text { Data } \\
\text { Sampel Biji } \\
\text { Kelapa } \\
\text { Sawit Grad } \\
\text { E }\end{array}$ & 1 & 1 & 5 & 3 \\
\hline
\end{tabular}

Normalisasi Matrix

Normalisasi matrix pencocokan yang sudah terkonversi adalah langkah yang selanjutnya dilakukan. Adapun rumus untuk menormalisasi adalah sebagai berikut

Dengan menggunakan data yang sudah dipaparkan di atas maka hasilnya adalah sebagai berikut:

$$
\begin{aligned}
& \mathrm{C} 1=\sqrt{7^{2}+6^{2}+5^{2}+2^{2}+1^{2}} \\
& =10.7239 \\
& \mathrm{C} 2=\sqrt{5^{2}+5^{2}+5^{2}+1^{2}+1^{2}} \\
& =8.7750
\end{aligned}
$$

$$
\begin{aligned}
& \text { C3 }=\sqrt{1^{2}+2^{2}+4^{2}+5^{2}+5^{2}} \\
& =8.4262 \\
& \mathrm{C} 4=\sqrt{5^{2}+3^{2}+3^{2}+3^{2}+4^{2}} \\
& =8.2463
\end{aligned}
$$$$
\mathrm{A}_{1}=7 / 10.7239
$$$$
=0.6528
$$$$
\mathrm{A}_{2}=5 / 8.7750
$$$$
=0.5699
$$$$
\mathrm{A}_{3}=1 / 8.4262
$$$$
=0.1187
$$$$
\mathrm{A}_{4}=5 / 8.2463
$$$$
=0.6064
$$$$
\mathrm{A}_{11}=6 / 10.7239
$$$$
=0.5595
$$$$
\mathrm{A}_{12}=5 / 8.7750
$$$$
=0.5699
$$$$
\mathrm{A}_{13}=2 / 8.4262
$$$$
=0.2374
$$$$
\mathrm{A}_{14}=3 / 8.2463
$$$$
=0.3638
$$$$
\mathrm{A}_{21}=5 / 10.7239
$$$$
=0.4664
$$$$
\mathrm{A}_{22}=5 / 8.7750
$$$$
=0.5699
$$$$
\mathrm{A}_{23}=4 / 8.4262
$$$$
=0.4748
$$$$
\mathrm{A}_{24}=3 / 8.2463
$$$$
=0.3638
$$

$\mathrm{A}_{31}=2 / 10.7239$

$=0.1865$

$\mathrm{A}_{32}=1 / 8.7750$

$=0.1140$

$\mathrm{A}_{33}=5 / 8.4262$

$=0.5934$

$\mathrm{A}_{34}=3 / 8.2463$

$=0.3638$

$$
\mathrm{S}_{\mathrm{i}}=\prod_{J=1}^{n} X_{i j} \mathrm{w}_{\mathrm{j}}
$$
$\mathrm{A}_{41}=1 / 10.7239$
$=0.0933$
$\mathrm{A}_{42}=1 / 8.7750$
$=0.1140$
$\mathrm{A}_{43}=5 / 8.4262$ 


$$
\begin{aligned}
& =0.5934 \\
\mathrm{~A}_{44} & =4 / 8.2463 \\
& =0.4851
\end{aligned}
$$

\subsection{Optimasi}

Setelah proses normalisasi matrix langkah selanjutnya adalah proses optimasi. Proses optimasi akan melakukan optimasi terhadap nilai-nilai kecocokan yang pada langkah seblumnya telah di normalisasikan. Proses optimasi akan ditampilkan pada Tabel 3.

Dan didapatkan hasil perkalian pada Tabel 4

Tabel 4 Hasil Kali

\begin{tabular}{|c|c|c|c|c|}
\hline \multirow{2}{*}{$\begin{array}{c}\text { Alte } \\
\text { rnat } \\
\text { if }\end{array}$} & \multicolumn{4}{|c|}{ Kriteria } \\
\cline { 2 - 5 } & $\begin{array}{c}\text { Fraksi } \\
\text { Kematang } \\
\text { an }\end{array}$ & Harga & $\begin{array}{c}\text { Jarak } \\
\text { Pengam } \\
\text { bilan }\end{array}$ & $\begin{array}{c}\text { Pernyata } \\
\text { an } \\
\text { Karantin } \\
\text { a }\end{array}$ \\
\hline A1 & 22.848 & 14.248 & 1.7805 & 16.16 \\
\hline A2 & 19.583 & 14.248 & 3.561 & 0.095 \\
\hline A3 & 16.324 & $14.248)$ & 7.122 & 9.095 \\
\hline A4 & 6.528 & 2.85 & 8.901 & 9.095 \\
\hline A5 & 3.266 & 2.25 & 8.901 & 12.128 \\
\hline
\end{tabular}

Tabel 5

Normalisasi

\begin{tabular}{|c|c|c|c|}
\hline \multirow{2}{*}{ Aternatif } & \multicolumn{3}{|c|}{ KRITERIA } \\
\cline { 2 - 4 } & $\begin{array}{c}\text { Maximum } \\
(\mathbf{C 1}+\mathbf{C 4})\end{array}$ & $\begin{array}{c}\text { Minimum } \\
\text { (C2 + C3) }\end{array}$ & $\begin{array}{c}\text { Yi }= \\
\text { Max - } \\
\text { Min }\end{array}$ \\
\hline A1 & 39.008 & 16.0285 & 22.9795 \\
\hline A2 & 19.678 & 17.809 & 1.896 \\
\hline A3 & 25.419 & 21.37 & 4.049 \\
\hline A4 & 15.623 & 11.751 & 3.872 \\
\hline A5 & 15.394 & 11.151 & 4.243 \\
\hline
\end{tabular}

\subsection{Perankingan}

Selanjutnya adalah melakukan perankingan dari hasil perhitungan optimasi sebelumnya. Adapaun hasil dari prosesperhitungannya adalah sebagaimana yang ditampilkan padaTabel 6

\begin{tabular}{|c|c|}
\hline Alternatif & Optimized Value \\
\hline A1 & 22.9795 \\
\hline A5 & 4.243 \\
\hline
\end{tabular}

\begin{tabular}{|l|l|}
\hline A3 & 4.049 \\
\hline A4 & 3.872 \\
\hline A2 & 1.896 \\
\hline
\end{tabular}

\begin{tabular}{|c|c|c|c|c|}
\hline \multirow{2}{*}{$\begin{array}{c}\text { Alte } \\
\text { rnat } \\
\text { if }\end{array}$} & $\begin{array}{c}\text { Fraksi } \\
\text { Kematangan }\end{array}$ & Harga & $\begin{array}{c}\text { Jarak } \\
\text { Pengam } \\
\text { bilan }\end{array}$ & $\begin{array}{c}\text { Pernyata } \\
\text { an } \\
\text { Karantin } \\
\text { a }\end{array}$ \\
\hline A1 & $0.6528 \times(35)$ & $\begin{array}{c}0.5699 \\
\times(25)\end{array}$ & $\begin{array}{c}0.1187 \\
\times(15)\end{array}$ & $\begin{array}{c}0.6064 \times \\
(25)\end{array}$ \\
\hline A2 & $0.5595 \times(35)$ & $\begin{array}{c}0.5699 \\
\times(25)\end{array}$ & $\begin{array}{c}0.2374 \\
\times(15)\end{array}$ & $\begin{array}{c}0.3638 \times \\
(25)\end{array}$ \\
\hline A3 & $0.4664 \times(35)$ & $\begin{array}{c}0.5699 \\
\times(25)\end{array}$ & $\begin{array}{c}0.4748 \\
\times(15)\end{array}$ & $\begin{array}{c}0.3638 \times \\
(25)\end{array}$ \\
\hline A4 & $0.1865 \times(35)$ & $\begin{array}{c}0.1140 \\
\times(25)\end{array}$ & $\begin{array}{c}0.5934 \\
\times(15)\end{array}$ & $\begin{array}{c}0.3638 \times \\
(25)\end{array}$ \\
\hline A5 & $0.0933 \times(35)$ & $\begin{array}{c}0.1140 \\
\times(25)\end{array}$ & $\begin{array}{c}0.5934 \\
\times(15)\end{array}$ & $\begin{array}{c}0.4851 \times \\
(25)\end{array}$ \\
\hline
\end{tabular}

Tabel 3 Tabel Optimasi1.

Kesimpulan

Kesimpulan yang didapat dalam penelitian ini yaitu pembuatan sistem penunjang keputusan pemilihan biji kelapa sawit menggunakan metode MOORA antara lain adalah :

1. Telah berhasilnya dibangun satu sistem penunjang keputusan dalam pemeilihan biji kelapa sawit dengan menggunakan metode perhitungan MOORA.

2. Sistem yang telah dibangun dapat meghasilkan keputusan berupa urutan perankingan data biji kelapa sawit dari yang terbaik sampai dengan yang terendah.

3. Dengan adanya sistem penunjang keputusan maka secara langsung sistem akan menghasilkan output hasil hitung yang berupa tabel perankingan.

DAFTAR PUSTAKA

dsn, c. (2018, Maret 12). DSS MOORA

Method. Retrieved

from cahyadsn.phpindonesia.id:

https://cahyadsn.phpindonesia.id/ext

ra/moora.php

Fazliani1, J. A. (2017). SISTEM PENDUKUNG

KEPUTUSAN PEMILIHAN JENIS BIBIT. SISTEM PENDUKUNG KEPUTUSAN PEMILIHAN JENIS BIBIT, 1-5.

Filsafat Waruwu, B. W. (2018).

PERTUMBUHAN BIBIT KELAPA SAWIT DI 


\section{PRE-NURSERY}

DENGAN. Jurnal ilmu-ilmu pertanian indonesia, 1-6.

Girsang, S. F. (2016). SISTEM PENDUKUNG KEPUTUSAN PEMILIHAN BIBIT KELAPA. SISTEM PENDUKUNG KEPUTUSAN PEMILIHAN BIBIT KELAPA, 1-18..

Riadi, M. (2016, September 18). Sistem Pendukung Keputusan (SPK).

Retrieved from KajianPustaka.com: https://www.kajianpustaka.com/201 3/09/sistempendukung-keputusan- spk.html

Rizky Hendro Agung, ,. S. (2020).

PENERAPAN METODE MULTI- OBJECTIVE OPTIMIZATION ON

THE. Jurnal Informatika Kaputama(JIK), Vol. 4 No. 1 ,

Januari 2020, 1-11.

Selviani Kusnad, ,. L. (2020). Sistem Pendukung Keputusan Pemilihan Lahan Untuk Tanam Bibit. Media Jurnal Informatika, 1-11 